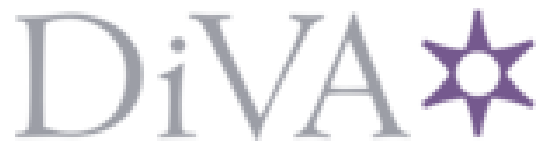

http://www.diva-portal.org

Preprint

This is the submitted version of a paper published in Journal of the Electrochemical Society.

Citation for the original published paper (version of record):

Törndahl, T., Ottosson, M., Carlsson, J-O. (2006)

Growth of Copper(I) Nitride by ALD Using Copper(II) Hexafluoroacetylacetonate, Water and Ammonia as Precursors

Journal of the Electrochemical Society, 153(3): C146-C151

https://doi.org/10.1149/1.2160427

Access to the published version may require subscription.

N.B. When citing this work, cite the original published paper.

Permanent link to this version:

http://urn.kb.se/resolve?urn=urn:nbn:se:uu:diva-92339 


\title{
Growth of Copper(I) Nitride by Atomic Layer Deposition using Copper(II) hexafluoroacetylacetonate, Water and Ammonia as Precursors
}

\author{
Tobias Törndahl*, Mikael Ottosson and Jan-Otto Carlsson \\ Dept. of Materials Chemistry, The Ångström Laboratory, University of Uppsala \\ Box 538, SE-75121 Uppsala, Sweden \\ Fax: +46 185135 48, E-mail: tobias.torndahl@mkem.uu.se
}

\begin{abstract}
Films of copper(I) nitride were deposited by Atomic Layer Deposition (ALD), using copper(II) hexafluoroacetylacetonate, water and ammonia as precursors. Introduction of a water pulse in the ALD cycle was found to be crucial for initiating film growth on both amorphous $\mathrm{SiO}_{2}$ and single crystalline $\alpha$ $\mathrm{Al}_{2} \mathrm{O}_{3}(001)$ substrates. The water pulses generated an oxidic copper monolayer, which in a subsequent ammonia pulse was converted to the nitride. The films have been grown in the temperature range from 210 to $302{ }^{\circ} \mathrm{C}$. Phase pure films of $\mathrm{Cu}_{3} \mathrm{~N}$ were obtained up to $265^{\circ} \mathrm{C}$. At higher deposition temperatures such as $283^{\circ} \mathrm{C}$, phase mixtures of $\mathrm{Cu}_{3} \mathrm{~N}$ and $\mathrm{Cu}$ were obtained. For temperatures above $302{ }^{\circ} \mathrm{C}$ films of only $\mathrm{Cu}$ were grown. Film growth rate was the same on the two different substrates. The films were randomly oriented on $\mathrm{SiO}_{2}$. Completely intact films were obtained at a thickness of $20 \mathrm{~nm}$. The optical band gap of the films was measured to $1.6 \mathrm{eV}$.
\end{abstract}


Keywords: Atomic layer deposition; Copper(l) nitride; $\mathrm{Cu}(\mathrm{hfac}) 2$; Sacrificial layers

$\mathrm{Cu}_{3} \mathrm{~N}$ is a semiconductor where the band gap varies with the nitrogen content. The experimentally measured band gaps for $\mathrm{Cu}_{3} \mathrm{~N}$ films with insulating character have been reported to be in the range 1.1 up to $1.8 \mathrm{eV} .^{1-6}$ Films of $\mathrm{Cu}_{3} \mathrm{~N}$ can obtain a metallic character in copper rich environments, where band gaps as low as $0.25 \mathrm{eV}$ have been measured for films with low resistivity values and larger unit cells. ${ }^{1,7}$ The copper rich films may be seen as phase mixtures of copper and copper(I) nitride grains. At the copper rich side a $\mathrm{Cu}_{4} \mathrm{~N}$ phase has also been proposed, where the extra copper atom is incorporated in the larger hole at the center of the $\mathrm{Cu}_{3} \mathrm{~N}$ unit cell. ${ }^{1,8}$ However, theoretical calculations indicate that such a phase is not stable unless the conditions are very copper rich. ${ }^{9}$ The metastability and the possibility of varying the band gap of $\mathrm{Cu}_{3} \mathrm{~N}$ may offer a unique set of applications to be exploited in areas like microelectronics, optical data storage and solar energy technology. In the literature, decomposition temperatures of the $\mathrm{Cu}_{3} \mathrm{~N}$ phase have been reported to be as low as $100{ }^{\circ} \mathrm{C}$ in vacuum. ${ }^{10}$ It has also recently been demonstrated that the metastability of the $\mathrm{Cu}_{3} \mathrm{~N}$ can be used for patterning of the films. For example, dot patterns, obtained by argon ion etching ${ }^{11}$ and by electron beam radiation, ${ }^{12}$ are reported as well as conducting copper lines produced by laser writing. ${ }^{13}$ These patterns might be used for optical data storage applications. ${ }^{14}$

Another interesting tentative large application of $\mathrm{Cu}_{3} \mathrm{~N}$ films, using the metastability, might be for metallisation in microelectronics. Copper films may be 
produced via the nitride and a subsequent short annealing. This might offer advantages with respect to growth rate, morphology, surface roughness, grain size, adhesion and nucleation instead of direct deposition of copper metal. In chemical processes such as Chemical Vapour Deposition (CVD) and Atomic Layer Deposition (ALD) hydrogen is by far the most frequently used reducing agent when growing copper thin films. Copper deposition processes are therefore mainly controlled by the activation of the hydrogen. Thus, the relative inertness of hydrogen leads to the need of using higher deposition temperatures to obtain a reasonable film growth rate. Higher deposition temperatures also affect copper surface mobility and interfacial reactions and rough films and phase mixtures formed upon reaction between film and substrate materials (barrier) might be the outcome.

Films of $\mathrm{Cu}_{3} \mathrm{~N}$ have been successfully produced by sputtering methods using copper and nitrogen as source materials. ${ }^{1,3-5,10,15-17}$ Other used $\mathrm{Cu}_{3} \mathrm{~N}$ deposition methods are $\mathrm{MBE}^{6}$ and ablation of copper in a nitrogen ambient. ${ }^{18}$ $\mathrm{Cu}_{3} \mathrm{~N}$ films have also been grown by $\mathrm{CVD}^{19}$. The main focus in this paper is to explore possibilities of low-temperature growth of $\mathrm{Cu}_{3} \mathrm{~N}$ by using the ALD method and a new process concept. After a copper precursor $\left(\mathrm{Cu}(\mathrm{hfac})_{2}\right)$ pulse an oxide/hydroxide monolayer is generated in a subsequent water pulse. The nitride is finally formed by introducing ammonia in the next pulse. Hence the oxide/hydroxide monolayer will act as sacrificial layers, opening for new reaction channels. The films are grown on two different oxide substrates, amorphous $\mathrm{SiO}_{2}$ and single crystalline $\alpha-\mathrm{Al}_{2} \mathrm{O}_{3}(001)$. Since a thermally activated process is used, 
nitrogen gas can no longer be used as nitrogen source due to its inertness at lower temperatures. Instead, ammonia is used as nitrogen source. $\mathrm{Cu}(\mathrm{hfac})_{2}$ is used as copper source due to its high vapour pressure and high reactivity at lower deposition temperatures. In some previous studies of copper growth by CVD/ALD, water has been used to enhance film nucleation and growth rate..$^{20-23}$ The addition of water was also found to have a large effect on copper film growth on the same substrate types as used in this study. ${ }^{24}$ In this work, two different ALD sequences are applied, one including water (pulse sequence: $\mathrm{Cu}(\mathrm{hfac})_{2} / \mathrm{H}_{2} \mathrm{O} / \mathrm{NH}_{3}$ ) and one without water (pulse sequence: $\mathrm{Cu}(\mathrm{hfac})_{2} / \mathrm{NH}_{3}$ ).

\section{Experimental}

Films of copper $(\mathrm{I})$ nitride $\left(\mathrm{Cu}_{3} \mathrm{~N}\right)$ have been grown by Atomic Layer Deposition (ALD). In the ALD process, a copper(II) $\beta$-diketonate type precursor $\mathrm{Cu}$ (hfac)2-hydrate $[\mathrm{Cu}(1,1,1,5,5,5$-hexafluoro-2,4-pentanedionate)2] also known as copper(II) hexafluoroacetylacetonate) was used as copper source material (99.99+\%-Cu, Strem Chemicals), together with water (de-ionised) and ammonia (99.995\%, Air Liquide) as other precursors. The effect of the water presence in the $\mathrm{Cu}(\mathrm{hfac})_{2}$ precursor on the deposition process is reported in the results and discussion section.

Films were grown in a five-zone hot wall ALD-reactor with a $60 \mathrm{~mm}$ silica reactor tube. The temperature in each zone was controlled individually. $\mathrm{Cu}(\mathrm{hfac}) 2$ was sublimated in the first two zones, while gas mixing and film growth occurred in the last zone. The reactants were transported into the deposition zone in five 
separate silica tubes in order to avoid gas mixing before the deposition zone. Instead, gas mixing occurred in a substrate block, placed in the deposition zone. The substrate block was made of nitrided titanium (TiN surface layer), in order to obtain a non-reactive surface. The metal block also gave a uniform temperature profile in the deposition zone. Of the five gas lines, three were designed for sublimation of solid precursors and two lines with a constant carrier gas flow for supply of other gaseous precursors such as water and ammonia. Five pneumatic valves, two for $\mathrm{Cu}(\mathrm{hfac})_{2}$, one for water and two for ammonia controlled pulsing of reactants into the growth region.

Water was vaporised from a glass vessel and carried into the system by effusion. The water partial pressure was controlled by a thermo-bath kept at 7.0 ${ }^{\circ} \mathrm{C}$. During water pulsing, a pneumatic valve opened to the evaporator and water was mixed with a constant flow of carrier gas. The ammonia pulsing was arranged in such a way that the gas was either admitted into a gas line (with a constant carrier gas flow) or via a bypass line to the pump side of the system.

A two tube line was used for sublimation of the $\mathrm{Cu}(\mathrm{hfac})_{2}$. The precursor was placed in a silica boat in an inner tube, inside an outer tube (with a constant flow of carrier gas). $\mathrm{Cu}(\mathrm{hfac})_{2}$ was then transported into the deposition zone with the carrier gas flowing through the inner silica tube, containing the precursor. The pulse was stopped by redirecting this flow to the outer tube. Furthermore, the gas flows were arranged in such a way that a small back flow over the precursor boat was utilised to abruptly abort the $\mathrm{Cu}(\mathrm{hfac})_{2}$ inlet during the ALD process. The $\mathrm{Cu}(\mathrm{hfac})_{2}$ precursor was sublimated at a temperature of $60{ }^{\circ} \mathrm{C}$. Prior to film 
deposition the $\mathrm{Cu}(\mathrm{hfac})_{2}$ precursor was heat-treated for $30 \mathrm{~min}$ at the sublimation temperature in order to remove the hydrate water.

Argon (99.9999\%, Air Liquide) was used as carrier gas at a total flow of 70 sccm in the five silica tubes leading into the substrate block. The argon flow corresponded to a linear flow velocity of $2.4 \mathrm{~m} / \mathrm{s}$ over the substrates in the deposition zone. Also, a bulk flow of argon was used outside the substrate block to obtain a flow in the main reactor tube.

The ALD growth process (ALD cycle) consisted of six steps. First, $\mathrm{Cu}(\mathrm{hfac})_{2}$ was adsorbed on the substrate surface, followed by argon purging to remove excess of precursor. After the purging, water was supplied and another purge pulse removed gaseous reaction products. Furthermore, an ammonia pulse was used to form the $\mathrm{Cu}_{3} \mathrm{~N}$ phase in an exchange reaction with the previously deposited copper oxide surface layer, thus acting as a sacrificial layer. Finally, argon purging was used to separate the precursor pulses. Typically used pulse durations within the ALD cycles in this study were $4 \mathrm{~s}$ for $\mathrm{Cu}(\mathrm{hfac})_{2}, 4 \mathrm{~s}$ for water and $4 \mathrm{~s}$ for ammonia. The argon purging after each precursor pulse was usually 6 or $8 \mathrm{~s}$ long. The mass inlet rate was normally $0,9 \mathrm{mg} / \mathrm{pulse}$ for $\mathrm{Cu}(\mathrm{hfac}) 2$ and $2.4 \mathrm{mg} /$ pulse for water, respectively, whereas the $\mathrm{NH}_{3}$ flow was kept at 42 sccm (corresponding to a partial pressure of $1.4 \mathrm{mbar}$ ). The deposition experiments were performed at temperatures ranging from 211 to $302{ }^{\circ} \mathrm{C}$ and at a total system pressure of 3.8 mbar. The temperature was measured with a thermocouple placed inside the substrate block. Fused silica $\left(\mathrm{SiO}_{2}\right)$ and single crystalline (001) oriented $\alpha-\mathrm{Al}_{2} \mathrm{O}_{3}$ were used as substrates, which were pre- 
treated in an ultra-sonic bath, rinsed in methanol and dried in a nitrogen flow prior to deposition. For the growth kinetic studies, $\mathrm{Cu}_{3} \mathrm{~N}$ films deposited on amorphous fused silica substrates were used.

Film thickness or the amount of deposited material per unit area was measured by energy dispersive X-Ray Fluorescence Spectrometry, XRFS (Spectro X-Lab 2000), using a $20 \mathrm{~mm}^{2}$ mask and a Mo-target. From XRFS the relative amount of deposited material can be obtained by integrating the intensities of characteristic peaks from the included elements. However, if an absolute thickness value is desired from XRFS, standards of known thicknesses have to be used. Thus, the measured XRFS results ( $\mathrm{Cu} \mathrm{K}_{\alpha}$ peak) were compared to copper standards prepared by evaporation on soda lime glass. The obtained film thickness, using the standards, were then multiplied by the density quotient $\rho(\mathrm{Cu}) / \rho\left(\mathrm{Cu}_{3} \mathrm{~N}\right)$ to get the corresponding $\mathrm{Cu}_{3} \mathrm{~N}$ thickness. Finally, no correction for absorption effects was required because of the fact that the films were very thin. Moreover, the film thickness was also measured by X-Ray Reflectivity, XRR (Siemens D5000, equipped with a slit system). From the XRR data, other parameters such as film density and roughness were also obtained from fitting the experimental data with the Wingixa program. The diffraction data for the nontextured films, deposited on $\mathrm{SiO}_{2}$, were collected with the grazing incidence technique (where the angle of incidence was kept around the critical angle $\sim 0.4^{\circ}$ for maximum intensity) by using a non-focusing geometry (Philips X'pert MRD, equipped with an X-ray mirror and parallel-plate collimator). The surface morphology of the films was studied with Scanning Electron Microscopy, SEM 
(Leo 1550 Gemini). Film surface and bulk contamination was examined by exsitu X-ray Photoelectron Spectroscopy, XPS (Quantum 2000 Phi), using monochromatic Al $\mathrm{K}_{\alpha}$ for sample excitation. Sputtering by argon ions was used to remove surface contamination and to determine the impurity level in the bulk. The film composition was calculated from sensitivity factors and XPS peak areas. InfraRed absorption spectra, IR (Perkin Elmer Spectrum One), were collected where the $\mathrm{Cu}(\mathrm{hfac})_{2}$ precursor was studied as paraffin mulls between $\mathrm{KBr}$ plates. Peaks due to the paraffin could not be successfully removed in the region of $3000-2700 \mathrm{~cm}^{-1}$. Optical data were collected with a spectrophotometer ${ }^{25}$ by measuring the reflectance and transmittance from the $\mathrm{Cu}_{3} \mathrm{~N}$ films. The absorbance as a function of photon energy was calculated by 1-R-T.

\section{Results and Discussion}

Precursor stability. Copper(II) hexafluoroacetylacetonate have been used as copper source in the growth process due to its high vapour pressure at lower temperatures. However, the precursor contains a small amount of water in its solid state and the effect of this water on the deposition process was for this reason studied separately. $\mathrm{Cu}_{2} \mathrm{O}$ films can be grown when switching the system into Chemical Vapour Deposition (CVD) mode by using $\mathrm{Cu}(\mathrm{hfac})_{2}$ and water as precursors. Both sublimation and adsorption studies of $\mathrm{Cu}(\mathrm{hfac})_{2}$ have been reported in the literature. The outcome of the studies is not entirely clear if $\mathrm{Cu}(\mathrm{hfac})_{2}$ is sublimated together with water in the form of clusters ${ }^{26}$ or independently from the water. ${ }^{19,27}$ The reports also indicate that the precursor 
undergo thermal decomposition under adsorption on surfaces at temperatures above $300{ }^{\circ} \mathrm{C} .{ }^{28,29}$ To investigate if the presence of water and the thermal stability of the $\mathrm{Cu}(\mathrm{hfac})_{2}$ precursor influenced film growth rate, experiments using only the copper containing precursor were carried out. Thus, an $8 \mathrm{~s}$ long precursor pulse, separated by a $20 \mathrm{~s}$ argon pulse, was repeated for 250 cycles at 247, 291 and $302{ }^{\circ} \mathrm{C}$ on both clean $\mathrm{SiO}_{2}$ substrates and on previously deposited $\mathrm{Cu}_{3} \mathrm{~N} / \mathrm{Cu}$ films. The precursor was heat-treated at the sublimation temperature, $60{ }^{\circ} \mathrm{C}$, for 30 min prior to the $\mathrm{Cu}(\mathrm{hfac}) 2$ pulsing. At 247 and $291{ }^{\circ} \mathrm{C}$, the film thickness measured by XRFS was the same (before and after the precursor pulsing), both on the $\mathrm{SiO}_{2}$ substrates and on the $\mathrm{Cu}_{3} \mathrm{~N} / \mathrm{Cu}$ films. This shows that the contribution to the growth rate from thermal decomposition and internal reaction is less than $5 \%$ of the total growth rate. However, at $302{ }^{\circ} \mathrm{C}$ copper was deposited both on the clean $\mathrm{SiO}_{2}$ substrates and onto a previously deposited copper film. The copper deposition was due to thermal decomposition of the precursor and corresponded to approximately $20 \%$ of the total copper content in a film grown at $302{ }^{\circ} \mathrm{C}$. Furthermore, TG studies indicated that the majority of the water in the precursor was evaporated separately at such a low temperature as $30{ }^{\circ} \mathrm{C}$. For example, when the temperature was cycled between room temperature and $40^{\circ} \mathrm{C}$, the mass loss was markedly larger during the first cycle. During all following cycles the TG curves were similar and the sublimation rate was the same. If all water is assumed to have been evaporated during the first cycle, a total amount of water in the un-treated precursor could be calculated to $0.2 \mathrm{H}_{2} \mathrm{O}$ per $\mathrm{Cu}(\mathrm{hfac})_{2}$ formula unit. Finally, IR spectra from the precursor before 
(Fig. 1a) and after annealing (Fig. 1b) were collected. The water has been evaporated during the annealing, which is indicated by the absence of characteristic $\mathrm{OH}$-stretch features in the range from 3700 to $3400 \mathrm{~cm}^{-1} .30 \mathrm{In}$ conclusion the pretreatment of the $\mathrm{Cu}(\mathrm{hfac})_{2}$ precursor was enough to remove the majority of the water and hinder internal reactions and thermal decomposition during the growth process according to the investigations with IR, XRFS and TG.

Growth kinetics. The growth rate of the copper(I) nitride as a function of precursor pulse lengths was tested at a deposition temperature of $247^{\circ} \mathrm{C}$. Film thickness, measured by XRFS, as a function of $\mathrm{Cu}(\mathrm{hfac})_{2}$ pulse length is shown in Fig. 2a. It can be seen that the growth rate increases rapidly up to approximately $4 \mathrm{~s}$ long precursor pulses. After $4 \mathrm{~s}$ the growth rate increases more slowly and the gain from longer pulse lengths starts to decrease. It can also be seen that saturation was not completely reached even after a $12 \mathrm{~s}$ long pulse. This might be due to several factors; bulky ligands, causing internal repulsion between the $\mathrm{Cu}(\mathrm{hfac})$ - adsorbates at higher surface coverages, thermal decomposition and competing deposition pathways. However, at a deposition temperature of $247^{\circ} \mathrm{C}$ no thermal decomposition of the precursor could be observed when measured by XRFS. Regarding bulkiness of ligands, similar saturation results when other metal organic precursors were used have also been reported in the literature. ${ }^{31,32}$

After pulsing with $\mathrm{Cu}(\mathrm{hfac})_{2}$ and purging with inert carrier gas, water was supplied to the deposition zone. The results from varying the water dose can be seen in Fig. 2b. The filled squares correspond to a water dose of $2.4 \mathrm{mg} / \mathrm{pulse}$ 
and the open circle to a $4.1 \mathrm{mg} / \mathrm{pulse}$ water dose. On the contrary to the $\mathrm{Cu}(\mathrm{hfac})_{2}$ pulsing, it was found that a saturation of the water pulse was reached after approximately $2 \mathrm{~s}$, indicating that the reaction was fast. During the water pulse, an oxide/hydroxide overlayer is thought to be formed as an intermediate step in the deposition process as compared to the water free process where $\mathrm{Cu}_{3} \mathrm{~N}$ was formed directly when ammonia reacted with the adsorbed $\mathrm{Cu}(\mathrm{hfac})_{2}$ precursor. It has been shown in CVD studies that the reaction product Hhfac etch copper(I) oxide. ${ }^{33,34}$ Thus, not only the pulse length of water but the water partial pressure could be important in the process as well. Practically no deposition of $\mathrm{Cu}_{3} \mathrm{~N}$ occurred when water was excluded from the growth process and only $\mathrm{Cu}(\mathrm{hfac})_{2}$ and $\mathrm{NH}_{3}$ was used as precursors. Moreover, an experiment where water was only supplied during the first 75 cycles, out of a total of 750 was carried out. During the final 675 cycles, only $\mathrm{Cu}(\mathrm{hfac})_{2}$ and ammonia were admitted into the reactor. It was found that the film deposited with a water start was $60 \%$ as thick as compared to a film where water had been supplied during all cycles on $\mathrm{SiO}_{2}$ substrates. The effect of adding water to the process have also been described for copper growth by ALD, using the same deposition scheme, but with $\mathrm{CuCl} / \mathrm{H}_{2} \mathrm{O} / \mathrm{H}_{2}$ precursor combinations. ${ }^{24}$

Ammonia was supplied as the third reactant. The influence of varying the ammonia partial pressure between 0 and 1.5 mbar can be seen in Fig. 2c. A steep increase in film growth rate can be observed when the $\mathrm{NH}_{3}$ partial pressure was increased from 0 to 0.33 mbar. After $0.33 \mathrm{mbar}$, the growth rate still increased up to $1.1 \mathrm{mbar}$, but at a much slower rate. At $1.4 \mathrm{mbar}$ the films were 
slightly thinner than at a 1.1 mbar ammonia partial pressure. $\mathrm{Cu}_{2} \mathrm{O}$ was deposited for a process scheme without $\mathrm{NH}_{3}$.

In Fig. 3., film thickness as a function of the number of ALD cycles for $\mathrm{Cu}_{3} \mathrm{~N}$ films grown at $247^{\circ} \mathrm{C}$ is shown. From the XRFS data in the graph, film growth rate was estimated to $0.35 \AA$ /cycle.

Film characterisation. Film composition/impurities of the films deposited with different ammonia partial pressures was measured ex-situ by XPS, both in the bulk of the films and on the film surfaces. Growth processes that use metal organic precursors may yield precursor residues in the films, mainly from carbon or other elements from the precursor ligands. Differences in film composition may occur for water or ammonia upon reaction with the adsorbed $\mathrm{Cu}(\mathrm{hfac})_{2}$ precursor. Therefore, an XPS analysis was also performed on a film where water was only supplied during the first 75 out of the 750 cycles. It was found that films deposited both with and without water contained precursor contaminations on the film surfaces in the form of three different types of carbon and fluorine. After cleaning of the surfaces by sputtering with argon ions, no silicon from the substrates or fluorine could be detected in the bulk. However, some differences were observed between the two growth processes. In the process where water was included, almost no carbon was detected in any of the films after sputtering. Since the amount of carbon was small and hardly distinguishable from the background, the total amount of carbon should be less than 1 at $\%$ in the films deposited with the water based process. On the contrary, much larger carbon content was detected in the film deposited without including water in the growth 
process. The carbon content was approximately four times as high as in the water free process. (An absolute value of the carbon content was measured to 2 at\%.) No major differences in film composition were detected for the $\mathrm{Cu}_{3} \mathrm{~N}$ films deposited with an ammonia partial pressure ranging from 0.33 to 1.4 mbar. However, it was found that the $\mathrm{Cu}_{3} \mathrm{~N}$ films contained oxygen in the bulk. To determine the oxygen content in the films, sensitivity factors for copper and oxygen were calculated by measuring (with the same XPS parameters) the atomic concentrations in a $\mathrm{Cu}_{2} \mathrm{O}$ film (narrow homogeneity range), deposited by CVD at the same deposition temperature. In the CVD film, no impurities were detected such as carbon and fluorine. Furthermore, no $\mathrm{Cu} 2 \mathrm{p}$ peak split could be detected in the bulk, indicating that the CVD film was not oxidised (no $\mathrm{Cu}(\mathrm{II})$ contribution). Thus, the oxygen content in the films was calculated to range from 3.7 to 5.2 at\%, assuming a copper concentration of 75 at\% in the $\mathrm{Cu}_{3} \mathrm{~N}$ films. However, films deposited without the addition of water also contained 2.3 at\% oxygen. The oxygen content in the bulk of the film, deposited without water, was the same after exposing the film to air for one month, indicating that the diffusion of oxygen into the film after film growth was slow. Under the assumption that the films contained 75 at\% copper the nitrogen content was estimated to approximately 20 at\% since the amount of other impurities, except for oxygen, were found to be low. No absolute determination of the copper to nitrogen ratio was done due to the fact that no standard samples with known $\mathrm{Cu} / \mathrm{N}$ composition was at hand for calculating new sensitivity factors. 
Diffractograms for films deposited with three different $\mathrm{NH}_{3}$ partial pressures (0, 0.33 and $1.4 \mathrm{mbar})$ are shown in Fig. 4. Diffractograms from films deposited at higher ammonia pressure than 0.33 mbar had the same appearance as that for 0.33 mbar. It was also found that the $\mathrm{Cu}_{3} \mathrm{~N}$ films were randomly oriented since the intensity distribution was roughly in agreement with intensities from diffraction data of bulk $\mathrm{Cu}_{3} \mathrm{~N} .{ }^{35}$

Film thickness as a function of deposition temperature is displayed in Fig. 5 and some corresponding diffractograms are shown in Fig. 6. It can be seen from Fig. 5 that film growth started at approximately $210{ }^{\circ} \mathrm{C}$, which was also the lowest deposition temperature for growth of copper(I) oxide in the system when ammonia was omitted. No difference in growth rate was observed for films deposited on fused silica and alumina in the given temperature range (210 to 302 $\left.{ }^{\circ} \mathrm{C}\right)$. After films started to grow at the lowest deposition temperatures, the growth rate increased with increasing deposition temperature up to approximately 280 ${ }^{\circ} \mathrm{C}$. From 280 to $300{ }^{\circ} \mathrm{C}$ a steep decrease in film growth rate was observed. The corresponding diffractograms (Fig. 6) show that phase pure films of $\mathrm{Cu}_{3} \mathrm{~N}$ were grown at lower deposition temperatures, whereas phase mixtures of copper(I) nitride and metallic copper were obtained at $283{ }^{\circ} \mathrm{C}$. At $302{ }^{\circ} \mathrm{C}$, the films consisted of mainly copper metal. However, the growth rate was still markedly lower at $302{ }^{\circ} \mathrm{C}$, even if it was taken into account that the films consisted of copper instead of copper(I) nitride. (The density quotient between bulk $\mathrm{Cu} / \mathrm{Cu}_{3} \mathrm{~N}$ is $\sim 1.5$, which means that the same amount of copper atoms in a $\mathrm{Cu}_{3} \mathrm{~N}$ and in a $\mathrm{Cu}$ film will lead to a thinner $\mathrm{Cu}$ film.) Another possible explanation for the 
decrease in growth rate might be explained by an increased rate of precursor desorption, which may also result in nucleation problems.

No preferred orientation was observed on the fused silica substrates. For the metallic copper phase, peak positions were in good agreement with the diffraction data, ${ }^{36}$ whereas the $\mathrm{Cu}_{3} \mathrm{~N}$ peaks were found to be shifted 0.2 to $0.4^{\circ}$ to higher diffracting angles in $2 \theta$ (when the peak shifts from the grazing incidence method have been taken into account). The shifted peaks correspond to a $\mathrm{Cu}_{3} \mathrm{~N}$ cell parameter two to three hundreds of an $\AA$ smaller than the cell parameters determined for the bulk phase (3.814 ̊). Possible explanations of the smaller cell parameter might be due to residual stress or impurities in the films such as oxygen.

The morphology of the deposited films was characterised by SEM. Due to nucleation problems and island growth of the $\mathrm{Cu}_{3} \mathrm{~N}$ films, at $247^{\circ} \mathrm{C}$, a complete surface coverage of the substrates was not obtained until a film thickness of 20 $\mathrm{nm}$. At film thicknesses above $10 \mathrm{~nm}$, the $\mathrm{Cu}_{3} \mathrm{~N}$ grains started to coalesce and form larger connected film areas. Film morphology was roughly the same for films grown on the $\mathrm{SiO}_{2}$ and $\alpha-\mathrm{Al}_{2} \mathrm{O}_{3}(001)$ substrates. However, film morphology varied markedly with the deposition temperature as well. SEM images for films grown on fused silica substrates at three different deposition temperatures are shown in Fig. 7. It should also be noted that film morphology was roughly the same for films deposited on $\mathrm{SiO}_{2}$ and $\alpha-\mathrm{Al}_{2} \mathrm{O}_{3}(001)$ substrates. At $247{ }^{\circ} \mathrm{C}$ (Fig. 7a), homogeneous films were obtained and the lateral grain size was estimated to range from 10 to $40 \mathrm{~nm}$. Moreover, the grain size and roughness was 
approximately the same for films deposited with 500 cycles and upwards. In Fig. 7b, SEM images for the two phase film $\left(\mathrm{Cu}\right.$ and $\left.\mathrm{Cu}_{3} \mathrm{~N}\right)$ deposited at $283^{\circ} \mathrm{C}$ are shown. It can be seen that larger crystallites (around 100nm) have been formed on the film surface, spaced some micrometers apart. In the regions between the larger crystallites, indications of film decomposition at some areas can be observed. Due to the large diffusion rate of copper, one possible explanation is that the larger crystallites consist mainly of copper metal, obtained by the thermal decomposition of the nitride. At the highest deposition temperature (Fig. 7c), only larger copper grains around $50 \mathrm{~nm}$ existed. Films were not covering the entire substrate surface in this case, which might be due to poor nucleation conditions and/or large diffusion rates of copper on the given surfaces.

Film thickness from XRFS and XRR as a function of the number of ALD cycles for $\mathrm{Cu}_{3} \mathrm{~N}$ films grown at $247{ }^{\circ} \mathrm{C}$ has been shown in Fig. 3. From XRR, interesting properties such as film roughness and density can be calculated, apart from the film thickness by fitting of measured data. It was found that there was a good agreement between the thickness data measured with the two methods for films thicker than approximately $20 \mathrm{~nm}$, which was the thickness required to obtain completely intact films. As observed by SEM, films thinner than $20 \mathrm{~nm}$ often had areas of holes. This might explain why the XRR thickness values were larger than those measured by XRFS for the thinner films. The film thickness could not be determined by XRR for the film deposited with 250 cycles (corresponding to a $5 \mathrm{~nm}$ thick film according to XRFS). Furthermore, no changes in lateral grain size were detected by SEM when the number of 
deposition cycles increased. From XRR, the surface roughness was calculated to be in the region of 3 to $4 \mathrm{~nm}$ for the films deposited with 500, 750 and 1000 cycles. For calculation of the XRFS thickness, the density of $\mathrm{Cu}_{3} \mathrm{~N}$ has to be known since standards of copper were used. In the XRFS measurements a bulk $\mathrm{Cu}_{3} \mathrm{~N}$ density of $5.84 \mathrm{~g} / \mathrm{cm}^{3}$ was assumed. From the XRR measurements, the film density was found to be in the region of the bulk density.

The $\mathrm{Cu}_{3} \mathrm{~N}$ band gap was measured by optical methods. In the literature, band gaps have been reported to range from 0.25 up to $1.8 \mathrm{eV} \cdot{ }^{1-7}$ One commonly used method for calculating the onset band gap of absorption is to plot the absorption coefficient at different energies. The absorption coefficient can be calculated from the transmittance and reflectance, where different band gaps such as indirect or direct types result in different plots. Both indirect $\left(\propto \alpha^{1 / 2}\right)$ and direct models $\left(\propto \alpha^{2}\right)$ have been used previously. The onset band gap in this work has been determined by plotting the absorbance as a function of energy, where the band gap was determined from the intercept on the energy axis. A plot can be seen in Fig. 8, where a band gap of $1.6 \mathrm{eV}$ was obtained for a $\mathrm{Cu}_{3} \mathrm{~N}$ film deposited with $750 \mathrm{Cu}(\mathrm{hfac})_{2} / \mathrm{H}_{2} \mathrm{O} / \mathrm{NH}_{3}$ cycles on fused silica. Furthermore, the band gaps from films deposited with different $\mathrm{NH}_{3}$ partial pressures and with or without water included in the growth process all had band gaps within $0.1 \mathrm{eV}$ of each other.

The effect of adding water. In the $\mathrm{Cu}_{3} \mathrm{~N}$ growth process, the results of adding water have been described in the previous sections. The addition of water in pulses is supposed to produce an oxidic monolayer acting as a sacrificial layer 
for the nitride growth during the ammonia pulse. This illustrates a principle of mediating surface reactions by using intermediate pulses and sacrificial layers in ALD. Films have been grown by utilising a three-step process $\left(\mathrm{Cu}(\mathrm{hfac})_{2} / \mathrm{H}_{2} \mathrm{O} / \mathrm{NH}_{3}\right)$ and later on, film growth without including water. The fact that no films were obtained without adding water initially indicates that the $\mathrm{Cu}(\mathrm{hfac})_{2}$ precursor yields a low surface coverage on the oxide substrate surfaces. Thus, at least initially, hydroxyl groups on the substrate surface played an important role in the $\mathrm{Cu}_{3} \mathrm{~N}$ growth process. Hence, the initial film deposition was thought to take place during the $\mathrm{Cu}(\mathrm{hfac})_{2}$ pulse when the copper containing precursor reacted with previously adsorbed surface specimen (including hydroxyl groups or combinations of $-\mathrm{OH}-\mathrm{NH}_{\mathrm{x}}$ thereof). This could be verified by carrying out a test to determine if the water was only of importance in the beginning (during film nucleation) of the deposition process or if it affected the film growth rate during the entire deposition process. As shown in the growth kinetic section earlier, film growth of $\mathrm{Cu}_{3} \mathrm{~N}$ growth on top of $\mathrm{Cu}_{3} \mathrm{~N}$ occurred also without addition of water. It is probable that a reaction between $\mathrm{Cu}(\mathrm{hfac})_{2}$ and adsorbed hydroxyl groups on the substrate surface or vice versa was the rate determining step at lower deposition temperatures as long as the substrate was exposed to the vapour. Furthermore, the markedly lower growth rate (2-3 times) of $\mathrm{Cu}_{2} \mathrm{O}$ as compared to $\mathrm{Cu}_{3} \mathrm{~N}$ might be due to differences in etching behaviour towards the Hhfac reaction products or differences in adsorption behaviour between $\mathrm{Cu}_{3} \mathrm{~N}$ and $\mathrm{Cu}_{2} \mathrm{O}$ towards the precursors. Finally, addition of water into the growth process also affected the film composition. The differences in carbon content 
between the two deposition processes indicated that the addition of water led to surface reactions where the hfac ligands were kept intact during the adsorption and/or surface reactions in the ALD scheme. One possible explanation for the oxygen content in the water free films might be due to the fact that the $\mathrm{Cu}(\mathrm{hfac})_{2}$ ligands were not stable during the water free deposition process, which was also indicated by the higher carbon content in the films. Thus, the oxygen content may originate from the precursor ligands themselves.

\section{Conclusions}

In this investigation, films of copper(I) nitride films have been grown in the temperature range from 210 to $302{ }^{\circ} \mathrm{C}$. Copper(II) hexafluoroacetylacetonate, water and ammonia was used as precursors. Water has been used in an intermediate step for $\mathrm{Cu}_{3} \mathrm{~N}$ film deposition on both fused silica and single crystalline $\alpha-\mathrm{Al}_{2} \mathrm{O}_{3}(001)$ substrates and the advantage of using water in the ALD cycle has been demonstrated. It was found that adding water to the process (pulse sequence: $\mathrm{Cu}(\mathrm{hfac})_{2} / \mathrm{H}_{2} \mathrm{O} / \mathrm{NH}_{3}$ ) was a prerequisite to initiate film growth on the two oxide substrates. The $\mathrm{Cu}_{3} \mathrm{~N}$ growth rate on top of $\mathrm{Cu}_{3} \mathrm{~N}$ was similar for films grown with or without the addition of water.

Differences in film composition were detected in the films grown with the two pulse sequences. The films grown without the addition of water contained 2 at\% carbon whereas the films deposited with water contained a four times smaller amount of carbon. The larger carbon content in the water free films indicated that the hfac ligands in the precursor were more likely to crack when 
reacting directly with ammonia than with water. On the other hand the oxygen content was larger in the films where water was included in the growth process, 3.7 to 5.2 at $\%$ as compared to 2.3 at\% for the water free sequence. The oxygen content was approximately the same when the ammonia partial pressure was altered between 0.33 to $1.4 \mathrm{mbar}$, indicating a difficulty to remove excess oxygen during the ammonia step. No fluorine was detected in any of the films.

No difference in growth rate was observed between $\mathrm{SiO}_{2}$ and $\alpha$ $\mathrm{Al}_{2} \mathrm{O}_{3}(001)$ substrates. Phase pure films of $\mathrm{Cu}_{3} \mathrm{~N}$ were grown up to $265{ }^{\circ} \mathrm{C}$. However at a deposition temperature of $283^{\circ} \mathrm{C}$ peaks from copper metal started to emerge in the diffractograms. At $302{ }^{\circ} \mathrm{C}$, the films consisted almost entirely of copper metal. The initial morphology of the thinner films was rough due to nucleation problems and island growth. A complete surface coverage of the substrates was not reached until a film thickness of $20 \mathrm{~nm}$ at a deposition temperature of $247^{\circ} \mathrm{C}$. At film thicknesses of $15 \mathrm{~nm}$ up to $20 \mathrm{~nm}$, the substrate surface was almost completely covered except for a few holes. The $\mathrm{Cu}_{3} \mathrm{~N}$ grains started to coalesce in films around $10 \mathrm{~nm}$ thick, deposited at $247^{\circ} \mathrm{C}$. However for films thicker than $20 \mathrm{~nm}$, film morphology was insensitive to changes in film thickness. The lateral grain size was estimated to range between 10 to $40 \mathrm{~nm}$. 


\section{Acknowledgements}

Financial support from the Swedish Research Council is gratefully acknowledged. Mr Ola Wilhelmsson is acknowledged for his assistance with the XPS measurements.

\section{References}

1. T. Maruyama and T. Morishita, J. Appl. Phys., 78, 4104 (1995).

2. L. Soukup, M. Sicha, F. Fendrych, L. Jastrabik, Z. Hubicka, D. Chvostova, H. Sichova, V. Valvoda, A. Tarasenko, V. Studnicka, T. Wagner and M. Novak, Surf. Coat. Technol., 116-119, 321 (1999).

3. T. Nosaka, M. Yoshitake, A. Okamoto, S. Ogawa and Y. Nakayama, Thin Solid Films, 348, 8 (1999).

4. K. J. Kim, J. H. Kim and J. H. Kang, J. Cryst. Growth, 222, 767 (2001).

5. S. Ghosh, F. Singh, D. Choudhary, D. K. Avasthi, V. Ganesan, P. Shah and A. Gupta, Surf. Coat. Technol., 142-144, 1034 (2001).

6. D. M. Borsa and D. O. Boerma, Surf. Sci., 548, 95 (2004).

7. J. F. Pierson, Vacuum, 66, 59 (2002).

8. J. Blucher and K. Bang, Mater. Sci. Eng A., 117, L1 (1989).

9. M. G. Moreno-Armenta, A. Martinez-Ruiz and N. Takeuchi, Solid State Sci., 6, 9 (2004).

10. Z. Q. Liu, W. J. Wang, T. M. Wang, S. Chao and S. K. Zheng, Thin Solid Films, 325, 55 (1998).

11. M. Asano, K. Umeda and A. Tasaki, Jpn. J. Appl. Phys., 29, 1985 (1990). 
12. T. Nosaka, M. Yoshitake, A. Okamoto, S. Ogawa and Y. Nakayama, Appl. Surf. Sci., 169-170, 358 (2001).

13. L. Maya, Mater. Res. Soc. Symp. Proc., 282, 203 (1993).

14. R. Cremer, M. Witthaut, D. Neuschultz, C. Trappe, M. Laurenzis, O. Winkler and H. Kurz, Mikro. Acta, 133, 299 (2000).

15. S. Terada, H. Tanaka and K. Kubota, J. Cryst. Growth, 94, 567 (1989).

16. L. Maya, J. Vac. Sci. Technol. A, 11, 604 (1993).

17. S. O. Chwa and K. H. Kim, J. Mater. Sci. Lett., 17, 1835 (1998).

18. G. Soto, J. A. Diaz and W. de la Cruz, Materials Letters, 57, 4130 (2003).

19. J. Pinkas, J. C. Huffman, D. V. Baxter, M. H. Chisholm and K. G. Caulton, Chem. Mater, 7, 1589 (1995).

20. J.-Y. Kim, Y.-K. Lee, H.-S. Park, J.-W. Park, D.-K. Park, J.-H. Joo, W.-H. Lee, Y.-K. Ko, P. J. Reucroft and B.-R. Cho, Thin Solid Films, 330, 190 (1998).

21. A. V. Gelatos, R. Marsh, M. Kottke and C. J. Mogab, Appl. Phys. Lett., 63, $2842(1993)$.

22. H. A. Marzouk, J. Y. Kim, J. S. Kim, P. J. Reucroft, R. J. Jacob, J. D. Robertson and C. Eloi, Thin Solid films, 249, 27 (1994).

23. J. Huo, R. Solanki and A. McAndrew, J. Mater. Res., 17, 2394 (2002).

24. T. Törndahl, M. Ottosson and J.-O. Carlsson, Thin Solid Films, 458, 129 (2004).

25. P. Nostell, A. Roos and D. Rönnow, Rev. Sci. Instrum., 70, 2481 (1999). 
26. C.-M. Chiang, T. M. Miller and L. H. Dubois, J. Phys. Chem., 97, 11781 (1993).

27. B. Zheng, C. Goldberg, E. T. Eisenbraun, J. Liu, A. E. Kaloyeros, P. J. Toscano, S. P. Murarka, J. F. Loan and J. Sullivan, Mater. Chem. Phys., $41,173(1995)$.

28. M. B. Naik, W. N. Gill, R. H. Wentorf and R. R. Reeves, Thin Solid Films, 262, 60 (1995).

29. N. S. Borgharkar, G. L. Griffin, H. Fan and A. W. Maverick, J. Electrochem. Soc., 146, 1041 (1999).

30. K. Nakamoto, Infrared Spectra of Inorganic and Coordination Compounds, John Wiley \& Sons, New York (1963).

31. M. Ylilammi, Thin Solid Films, 279, 124 (1996).

32. M. Utriainen, M. Kröger-Laukkanen and L. Niinistö, Mater. Sci. Eng B., 54, 98 (1998).

33. M. A. George, D. W. Hess, S. E. Beck, J. C. Ivankovits, D. A. Bohling and A. P. Lane, J. Electrochem. Soc., 142, 961 (1995).

34. A. Sekiguchi, A. Kobayashi, T. Koide, O. Okada and N. Hosokawa, Jpn. J. Appl. Phys., 39, 6478 (2000).

35. U. Zachwieja and H. Jacobs, J. Less Common Met., 161, 175 (1990).

36. H. E Swanson and E. Tatge, Natl. Bur. Stand. (U.S.), Circ. 539, I, 15 (1953). 
Figure captions:

Fig. 1. IR spectra from the $\mathrm{Cu}(\mathrm{hfac})_{2}$ precursor. a) before annealing and b) after annealing at $40{ }^{\circ} \mathrm{C}$ for $60 \mathrm{~min}$.

Fig. 2. $\mathrm{Cu}_{3} \mathrm{~N}$ growth rate on $\mathrm{SiO}_{2}$ substrates at $247{ }^{\circ} \mathrm{C}$. a) as a function of $\mathrm{Cu}(\mathrm{hfac})_{2}$ pulse length, b) as a function of $\mathrm{H}_{2} \mathrm{O}$ pulse length and c) as a function of $\mathrm{NH}_{3}$ partial pressure.

Fig. 3. Growth rate of $\mathrm{Cu}_{3} \mathrm{~N}$ as a function of the number of ALD cycles for films deposited on $\mathrm{SiO}_{2}$ at $247^{\circ} \mathrm{C}$.

Fig. 4. X-ray diffractograms for films deposited with different $\mathrm{NH}_{3}$ partial pressures on $\mathrm{SiO}_{2}$ at $247{ }^{\circ} \mathrm{C}$ and 750 cycles. Peaks marked with filled diamonds correspond to the $\mathrm{Cu}_{2} \mathrm{O}$ phase. All unmarked peaks belong to the $\mathrm{Cu}_{3} \mathrm{~N}$ phase.

Fig. 5. $\mathrm{Cu}_{3} \mathrm{~N} / \mathrm{Cu}$ film thickness as a function of deposition temperature for films grown with 500 cycles on $\mathrm{SiO}_{2}$.

Fig. 6. X-ray diffractograms for films deposited with 500 cycles at different deposition temperatures on $\mathrm{SiO}_{2}$. Peaks marked with asterisks correspond to the $\mathrm{Cu}$ phase. All unmarked peaks belong to the $\mathrm{Cu}_{3} \mathrm{~N}$ phase. 
Fig. 7. SEM images for $\mathrm{Cu} / \mathrm{Cu}_{3} \mathrm{~N}$ films grown on $\mathrm{SiO}_{2}$ substrates at three different deposition temperatures. a) 1000 cycles at $247^{\circ} \mathrm{C}$, b) 500 cycles at 283 ${ }^{\circ} \mathrm{C}$ and c) 500 cycles at $302{ }^{\circ} \mathrm{C}$.

Fig. 8. Absorbance plot for a $\mathrm{Cu}_{3} \mathrm{~N}$ film deposited with 750 cycles at $247^{\circ} \mathrm{C}$. 
Fig. 1.

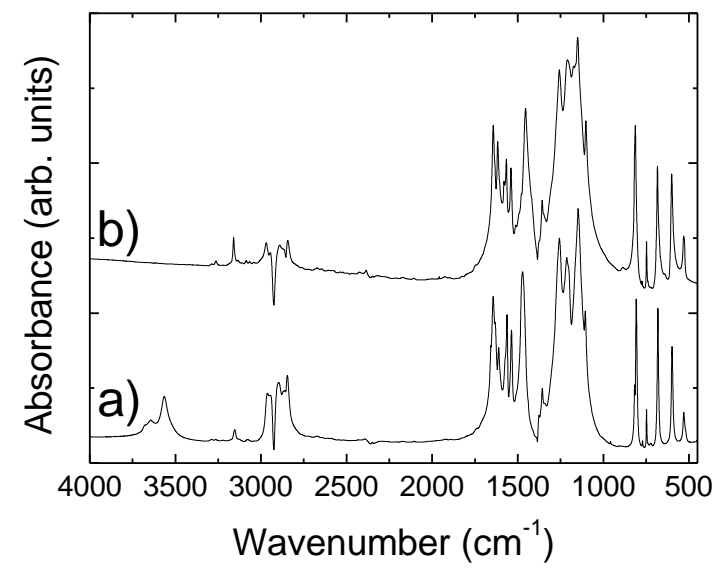


Fig. 2.
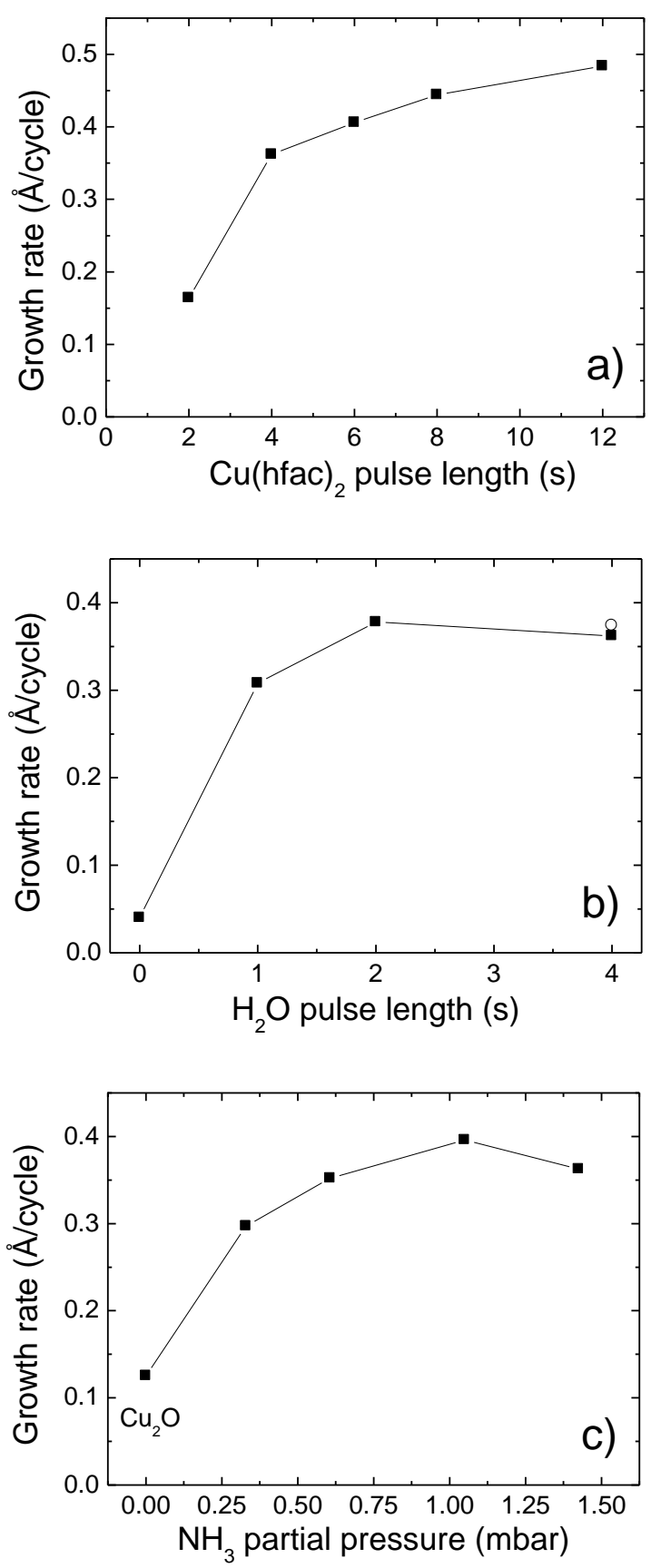
Fig. 3.

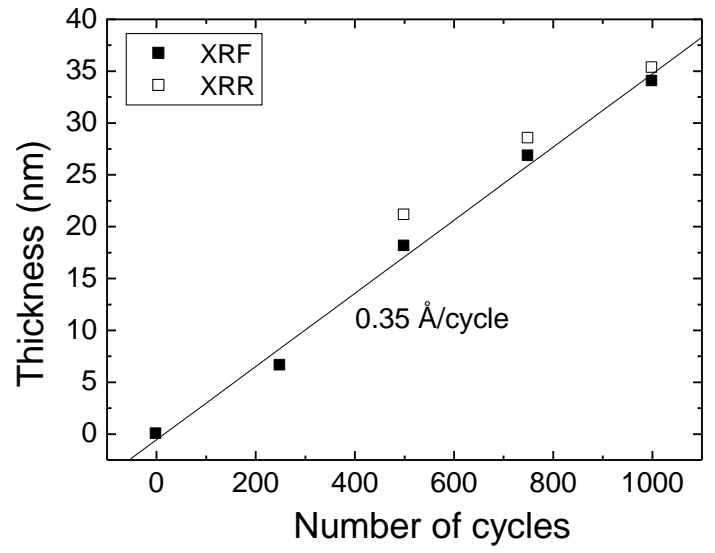


Fig. 4.

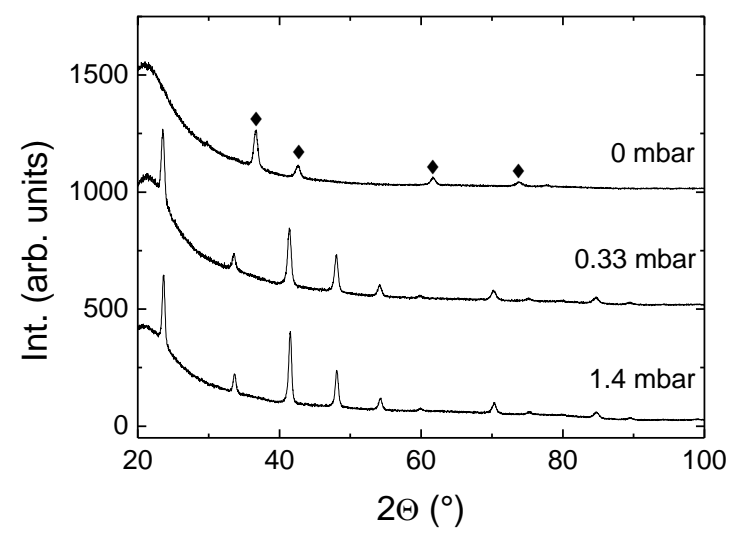


Fig. 5.

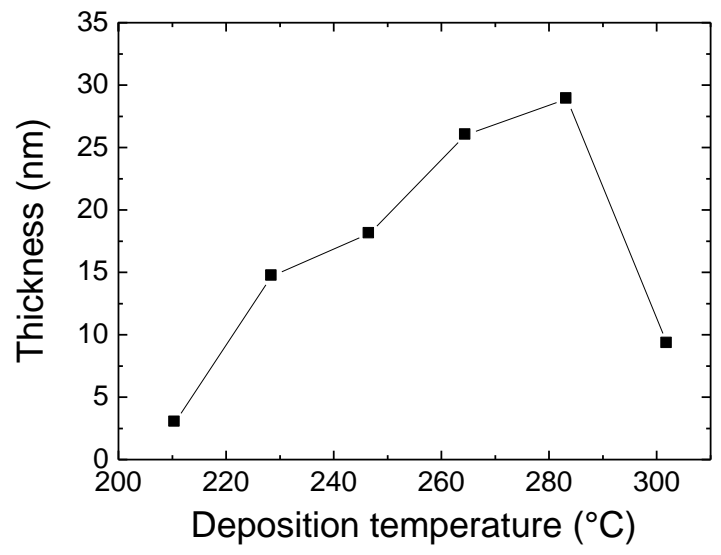


Fig. 6.

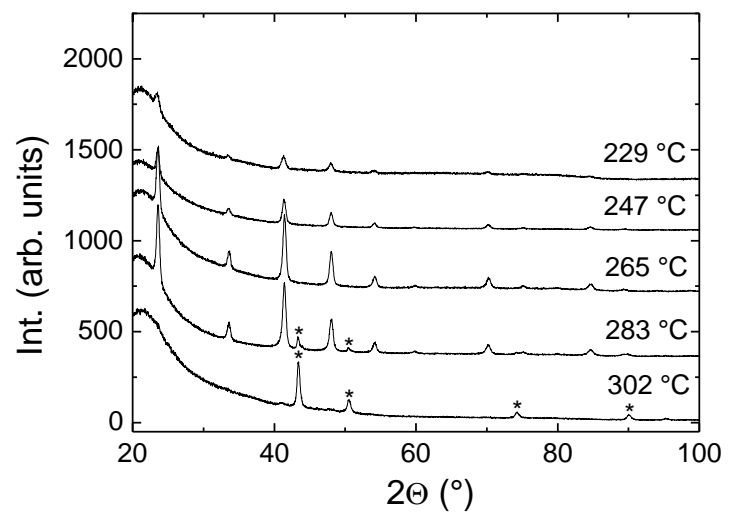


Fig. 7.
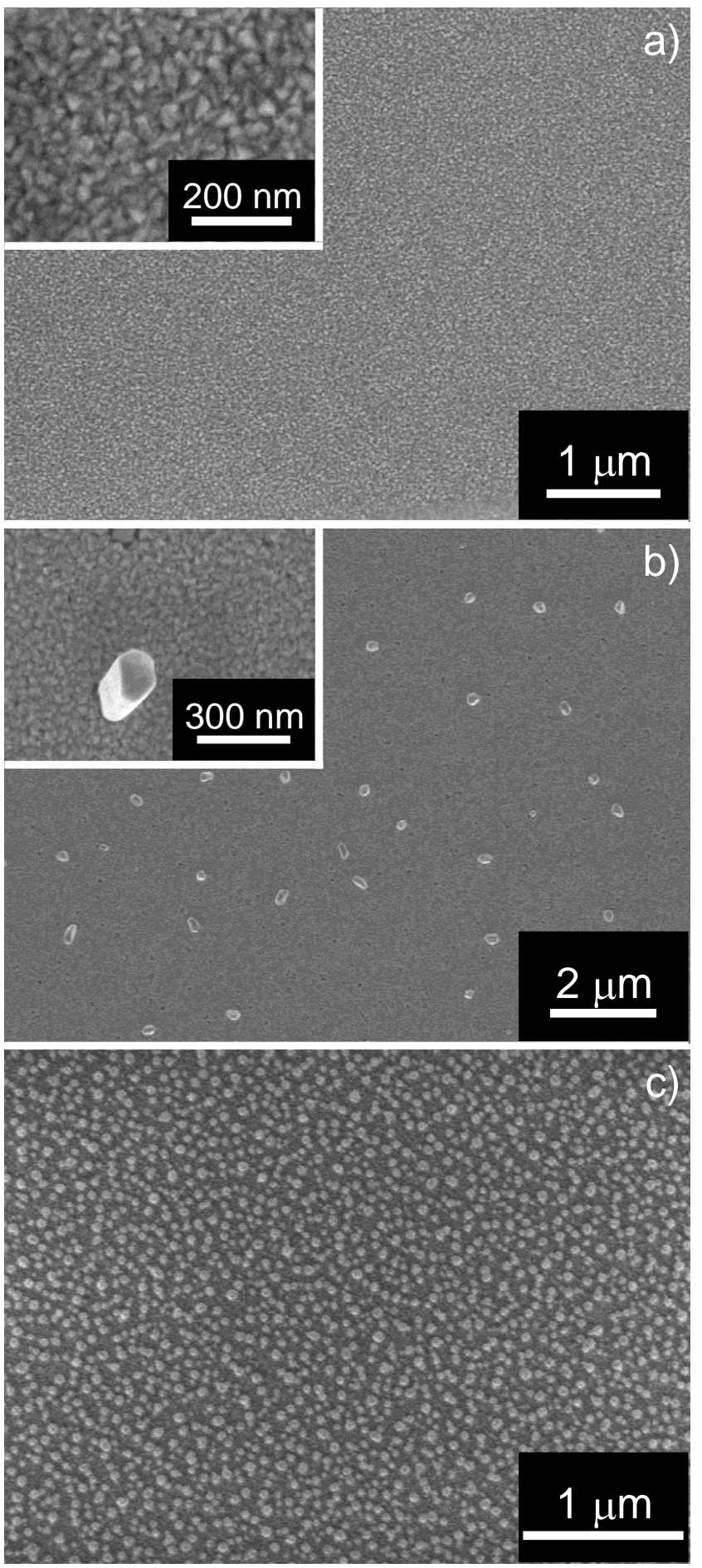
Fig. 8.

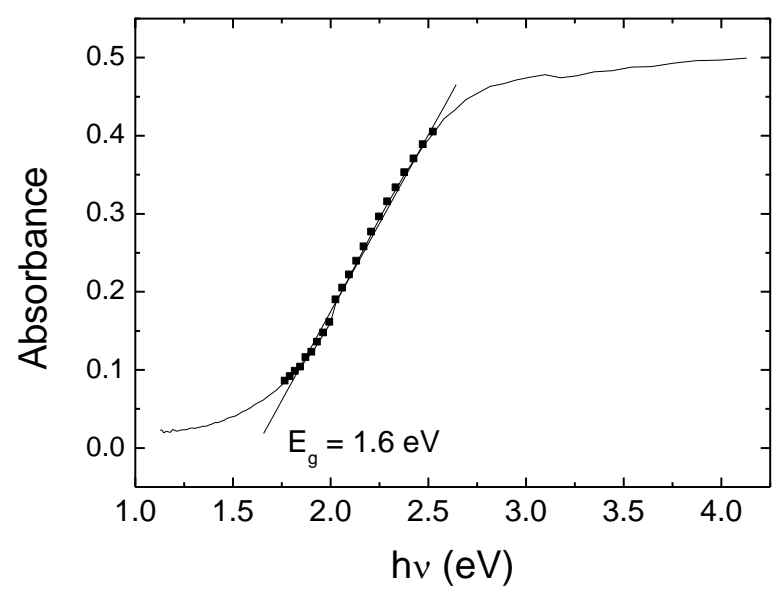

